\title{
AIDS-Related Diffuse Mixed Cell Lymphoma
}

National Cancer Institute

\section{Source}

National Cancer Institute. AIDS-Related Diffuse Mixed Cell Lymphoma. NCI Thesaurus.

Code C8296.

A non-Hodgkin lymphoma occurring in HIV-positive patients. It is composed of a mixture of lymphocytes of various sizes. 